\title{
Leaf epidermal features in relation to taxonomy of some species of Bulbophyllum (Orchidaceae) from Northeast India
}

\author{
Madhavi Singh ${ }^{1}$, Vimala Y. ${ }^{2}$, Lavania S. ${ }^{1 *} \&$ D. Verma ${ }^{3}$ \\ 'Department of Botany, University of Lucknow, Lucknow, Uttar Pradesh - 226007 , India. \\ ${ }^{2}$ Department of Botany, C.C.S. University, Meerut, Uttar Pradesh - 250 004, India. \\ ${ }^{3}$ Botanical Survey of India, Dehradun, Uttarakhand - 248 195, India. \\ *E-mail: lavaniaseshu@yahoo.co.in
}

\begin{abstract}
Twelve epiphytic species of the genus Bulbophyllum Thouars, including one endemic ( $B$. sunipia J.J.Verm., Schuit. \& de Vogel), collected from Northeast India (Meghalaya) were investigated for their leaf epidermal features using bright field and scanning electron microscopy (SEM) and hand sectioning. Features such as epidermal cell size, stomata type, stomatal complex size and index, trichome type and density, cuticular thickening pattern, number of subsidiary cells, number of stomatal rims and stomatal ledge aperture (SLA) shape were considered to generate data for their qualitative and quantitative assessment. The stomata in B. striatum (Griff.) Rchb.f. were found to be of the tetracyclocytic type, with 4-6 subsidiary cells, and a high density $\left(80.52 / \mathrm{mm}^{2}\right)$ and highest number of stomatal groups (14-16). Bulbophyllum cherrapunjeense Barbhuiya \& D.Verma exhibited some distinguishing features viz. lowest stomatal density $\left(17.61 / \mathrm{mm}^{2}\right)$, range of subsidiary cell number (3-5), area occupied by stomata $\left(0.017 \mathrm{~mm}^{2}\right)$, and maximum glandular trichome density $\left(235.27 / \mathrm{mm}^{2}\right)$ on the adaxial surface per $\mathrm{mm}^{2}$ of lamina, and smooth cuticular thickening. Characters like occurrence of stomatal rim, group arrangement of stomata (except in B. affine Wall. ex Lindl., B. cherrapunjeense and B. cauliflorum Hook.f.), epicuticular wax deposition on the surface and presence of scales (multicellular sessile glandular trichome) are reported for the first time for this genus. The study is important for species identification and provides some baseline data for future empirical studies on the taxonomic value of the studied leaf characters.
\end{abstract}

Keywords: Cuticular thickening, Cuticular wax, Epiphytes, Glandular trichomes, Stomatal ledge aperture (SLA).

Received: 30.03.2020; Revised \& Accepted: 10.11.2020

Published Online: 31.12.2020

\section{Introduction}

Angiosperm leaves are supposed to be the most varied anatomical organs (Metcalfe \& Chalk, 1950; Carlquist, 1961; Hickey, 1973). A large number of investigations (Baranova, 1972; Cutler, 1979; Barthlott, 1981; Rindiyastuti et al., 2018) have examined the diagnostic value of leaves. The anatomy of leaves holds huge significance in plant identification and is a valuable taxonomic parameter (Aybeke et al., 2010). Leaf epidermal characters have proven important in classification (Stace, 1965, 1984), and have been frequently studied for taxonomic purpose in several taxa (Wang \& Tao, 1993; Luo \& Zhou, 2001; Shi \& Li, 2003; Ren et al., 2007). Studies on leaf epidermal characters of the families Polygonaceae in West Africa (Ayodele and Olowokundejo, 2006) and Moraceae (Ogunkunle, 2013), and some species of family Fabaceae by Saheed and Illoh (2010) have been found to be of considerable taxonomic significance. There is abundant recent literature on leaf epidermal attributes that illustrate their taxonomic value among dicotyledons and monocotyledons (Tomlinson, 1961, 1969; Ahmad, 1964; Inamdar, 1970; Gilani et al., 2002; Agbagwa \& Okoli, 2006; Adedeji \& Jewoola, 2008; Moore et al., 2010; Fan et al., 2014).

Orchidaceae is one of the highly evolved and largest families of the order Asparagales with approximately 25,000 to 35,000 species belonging to 750 to 850 genera distributed worldwide (Dressler, 1981; Chase et al., 2005; Saito, 2006; 
Hossain, 2011; Seberg et al., 2012). The members of family Orchidaceae are found in every biome such as the arctic-circle, semi-desert, semi-arid, aquatic, some are temporarily submerged during periodic flooding, on mangrove trees in estuaries and even adapted to salt spray (Hágsater et al., 2005; Jones, 1988). Atwood (1986) estimated that 73\% of species of Orchidaceae are epiphytic. The diversity of orchids and their habitat lead to anatomical, morphological and ecological variation (Mehra \& Vij, 1974; Rao \& Khasim, 1986; 1987; Pridgeon, 1986; Arditti, 1992; Stern \& Morris, 1992).

The family Orchidaceae has always been of great interest to taxonomists for elucidating its evolutionary status, distribution, habitat, pollination mechanism, foliar micromorphology, floral morphology and anatomy. However, some consistent lacunae in study of vegetative anatomy are evident from the available literature. The earliest records on orchid anatomy were seen in the work carried out by Chatin (1856), Möbius (1887), Sprenger (1904) and Solereder and Meyer (1930). Williams (1974) stressed the usefulness of anatomical data in orchid taxonomy that led to studies on the anatomy of leaf, stem and root. Such studies of Dresslerella Luer (Pridgeon \& Norris, 1979) and subtribe Pleurothallidinae Lindl. ex G.Don (Pridgeon, 1982), and on the leaf of Caladenia R.Br. (Pridgeon, 1993) and Dendrobium Sw. (Carlsward et al., 1997), the root and leaf of tribe Habenariinae Verm. (Stern, 1997a), and on the root of members of subtribe Orchidinae Verm. (Stern, 1997b) are worth mentioning. Subsequently other studies appeared on the comparative vegetative anatomy of various tribes and subtribes of family Orchidaceae viz., Calypsoeae Dressler, and subtribes Laeliinae Benth., Oncidiinae Benth. \& Hook. f., and Vanillinae Meisn. for their systematic and taxonomic significance (Stern \& Judd, 2000; Stern \& Carlsward, 2006, 2008, 2009). During recent years the anatomical features of the members of Orchidaceae have been used to support their identification and classification (Aybeke et al., 2010; Fan et al., 2014).

In India, leaf epidermal features of orchids were first studied by Vij et al. (1991), while Das and Paria (1992) investigated the stomatal structure of some Indian orchids with reference to taxonomy. The leaf anatomy of epiphytic orchids were studied by Oliveira and Sajo (1999), Arevalo et al. (2011). Mulgaonkar (2005) studied the epidermal anatomy of three Indian corticolous orchids and noted the relationship between epidermal characters and environmental conditions.

The Pantropical orchid genus Bulbophyllum Thouars belongs to the subfamily Epidendroideae Kostel., tribe Dendrobieae Lindl. ex Endl., subtribe Bulbophyllinae Schltr. It is estimated to contain 1,700 species (Dressler, 1993; Fischer et al., 2007; Sieder et al., 2007), and as such is considered as one of the largest genera among all vascular plants. It is one of the most important genera of the family for its diversity, different growth forms and morphological and anatomical characters. (Vermeulen, 1991; Dressler, 1993; Smidt et al., 2011). It comprises nearly $5 \%$ of all orchids, with about 100 species reported from India of which 63 species are from the Northeast (Augustine et al., 2001; Misra, 2007). Sehgal and Mehra (1984) studied the distribution pattern of orchids in Khasi and Jaintia Hills of Meghalaya state, and Kataki (1986) reported 28 species of Bulbophyllum from this state.

Much work has been done on the floral anatomy of Bulbophyllum reflecting their use as diagnostic characters in systematics (Blanco et al., 2013; Davies \& Stpiczynska, 2014; Nunes et al., 2014). However, the literature on the anatomy of vegetative parts such as root, bulb and leaf of the genus Bulbophyllum is meager necessitating the need for further exploration. The first record on root anatomy of Bulbophyllum including B. careyanum (Hook.) Spreng. dates back to 1856 when Chatin examined the structure and function of the root in several orchids. Such earlier investigations reported mostly 
the root anatomy - as cited in Genera Orchidacaerum by Pridgeon et al. (2014) - while the leaf anatomical descriptions of several Bulbophyllum species were published by Möbius (1887), followed by leaf anatomical studies on some species of the genus (Tominski, 1905; Oliver, 1930; Pridgeon et al., 2014). Kaushik (1983) investigated the anatomy of petiole, pseudobulb, rhizome and root including leaf blade of B. reptans (Lindl.) Lindl. ex Wall.. Rao and Khasim (1987) studied the anatomy of three species of Bulbophyllum. Piazza et al. (2015) studied the anatomy of leaf, pseudobulb and root of 13 species of Bulbophyllum to ascertain the importance of anatomical features in systematics. Muthukumar and Shenbagam (2018) worked on the leaf, root and pseudobulb anatomy of B. sterile (Lam.) Suresh. Seemingly, anatomical and morphological investigations have been carried out on many species of Bulbophyllum in different parts of the world. However, study on the anatomy and epidermal micromorphology on Bulbophyllum species in India has largely remained unexplored. Therefore, the present investigation was undertaken for developing morpho-anatomical data based on epidermal features to facilitate elucidation of interspecific taxonomic affinities in future studies.

\section{Materials and Methods}

\section{Collection and identification of samples}

Twelve epiphytic species of Bulbophyllum were collected from different localities from their natural environment in Meghalaya State, India (Table 1). The taxonomic identities of the plants were determined with the help of herbarium specimens available at the Botanical Survey of India, Shillong (Meghalaya) and the World Checklist of the Royal Botanic Gardens, Kew (https://wcsp.science. kew.org/qsearch.do). A detailed study of the leaf epidermal micromorphology of each taxon was carried out. The epidermal characters were examined as suggested by Metcalfe (1960) for grasses and Williams (1975) for orchids. The terminology for the description of leaf epidermal characters was adopted from Metcalfe (1961), Stace (1965), Fahn (1979) and Baranova (1992).

\section{Preparation for light microscopic examinations}

Leaves of the studied species are simple with a basal pseudobulb, petiolate, sub-sessile or sessile,

Table 1. Taxa, distribution and altitude of species of Bulbophyllum used in the present study

\begin{tabular}{|l|l|l|c|}
\hline S.No. & Taxon & Collection site & Altitude (m) \\
\hline 1. & B. affine Wall. ex Lindl. & Mukhaialong Community Reserve, Jaintia Hills, Meghalaya & $100-1800$ \\
\hline 2. & B. ambrosia (Hance) Schltr. & $\begin{array}{l}\text { Planted at Botanical Survey of India, Eastern Regional Centre } \\
\text { Garden, Shillong (collected from Mizoram) }\end{array}$ & $300-1300$ \\
\hline 3. & B. bisetum Lindl. & Cherapunjee, Khasi Hills, Meghalaya & $1500-2000$ \\
\hline 4. & B. cauliflorum Hook.f. & Chyrmang Community Reserve, Jaintia Hills, Meghalaya & $600-2000$ \\
\hline 5. & $\begin{array}{l}\text { B. cherrapunjeense } \\
\text { Barbhuiya \& D.Verma }\end{array}$ & Cherapunjee, Khasi Hills, Meghalaya & 1460 \\
\hline 6. & B. gymnopus Hook.f. & Chyrmang Community Reserve, Jaintia Hills, Meghalaya & $600-2000$ \\
\hline 7. & $\begin{array}{l}\text { B. leopardinum (Wall.) } \\
\text { Lindl. ex Wall. }\end{array}$ & Mukhaialong Community Reserve, Jaintia Hills, Meghalaya & $1300-3300$ \\
\hline 8. & B. pteroglossum Schltr. & Upper Shillong, Khasi Hills, Meghalaya & $1000-2500$ \\
\hline 9. & $\begin{array}{l}\text { B. reptans (Lindl.) Lindl. } \\
\text { ex Wall. }\end{array}$ & Tuber Community Reserve, Jaintia Hills, Meghalaya & $300-1600$ \\
\hline 10. & B. striatum (Griff.) Rchb.f. & Tuber Community Reserve, Jaintia Hills, Meghalaya & $1500-2330$ \\
\hline 11. & $\begin{array}{l}\text { B. sunipia J.J.Verm., } \\
\text { Schuit. \& de Vogel }\end{array}$ & Chyrmang Community Reserve, Jaintia Hills, Meghalaya & $900-2300$ \\
\hline 12. & B. umbellatum Lindl. & Upper Shillong, Khasi Hills, Meghalaya & $1000-2200$ \\
\hline
\end{tabular}


succulent or less succulent. They are sessile in $B$. cherrapunjeense and B. cauliflorum. The leaf shape varied from oblong to linear oblong, narrowly oblong to elliptic oblong. The leaf apex is mostly obtuse or less frequently acute with a notched tip.

Fresh mature leaves were fixed in FAA prepared with $50 \%$ ethanol then preserved in 70\% ethanol according to Johansen (1940). The samples for bright field microscopy were taken from the least variable region of the leaf i.e., the mid-lamina as suggested by Wilkinson (1979). Epidermal peels were removed using a razor blade as described by Johansen (1940), thereafter scraped from the inner side to leave only the epidermis by removing undesired cell layers. Glycerine mounts of hand cut leaf transverse sections and epidermal peels were stained with 1\% safranin (prepared in 70\% alcohol) for micromorphological examinations. Photomicrographs were taken under daylight without using filters under a Nikon-H600L microscope (Tokyo, Japan) at desired magnifications. Ten samples per individual were collected and three individuals were sampled for each species.

\section{Sample preparation for scanning electron microscopic examinations}

To examine the ultra-micromorphology of the leaf epidermis, scanning electron microscopy (SEM) was used. A piece of $<0.5 \mathrm{~cm}^{2}$ leaf lamina from the central lamina region was taken. Sample pieces were washed and shade dried for 60 days. The dried samples were placed on metallic stubs with the help of double-sided adhesive tape keeping exposed the surface to be observed. The samples were coated with a Platinum Sputter Coater (JEOL, JFC 1600, Auto Fine Coater, Tokyo, Japan) and scanned using a JEOL JSM 6490 LV (Tokyo, Japan) scanning electron microscope. Photomicrographs were taken at desired magnifications.

\section{Data generation and analysis}

Numerical data were obtained by recording the number of ocular divisions for measuring cellular dimensions (i.e., length and breadth), and for the number / density of epidermal surface structures such as stomata, epidermal cells, trichomes and scales. All numerical length data were converted to measurable units after calibration with a stage micrometer (the smallest count of the stage micrometer was $0.01 \mathrm{~mm}$ ). At least 10 observations were recorded for each parameter. The results were presented as means \pm standard error of the mean (SE). Statistical analyses were carried out using the analysis ToolPak in Microsoft Excel to calculate correlation coefficients $\left(\mathrm{r}^{2}\right)$ on the means to deduce interactions between pairs of epidermal characters.

\section{Results}

All observations on micromorphological characters and quantitative assessments of epidermal surface features are listed in Tables $2 \& 3$ and illustrated in Figs. 1, 2, $3 \& 4$. The means of quantitative epidermal characters such as epidermal cell density, stomatal index, glandular trichome density and size of the stomatal complex varied greatly (Table 3). A positive correlation was found between stomatal density and epidermal cell density $\left(\mathrm{r}^{2}=0.5483\right.$, $P<0.01)$, glandular trichome density of both abaxial $\left(\mathrm{r}^{2}=0.5828, P<0.01\right)$ and adaxial $\left(\mathrm{r}^{2}=0.5639\right.$, $P<0.01)$ surfaces and the stomatal index $\left(\mathrm{r}^{2}=0.5828\right.$, $P<0.01)$, and a negative correlation between stomatal complex size and glandular trichome density of the abaxial surface $\left(\mathrm{r}^{2}=0.4087, P<0.025\right)$.

Epidermal cells: Epidermal cells on both leaf surfaces were polygonal (Figs. 1a-k, 2a-k), except for $B$. reptans where the cells were rectangular to polygonal arranged in a parallel manner (Fig. 1 \& 2). The epidermal cells on the adaxial surface were straight walled except in $B$. reptans where the anticlinal wall curved / arched (Fig. 2). Cells on the abaxial surface of $B$. reptans were axially elongated so their length was more than the breadth, while those on the adaxial surface had a virtually equal length and breadth (Fig. 11). The cell wall of abaxial epidermal cells in all species was non-sinuous to arched and thick walled (Figs. 1 \& 2). The epidermal cell walls on both surfaces had pit connections. The ratio of abaxial : adaxial 

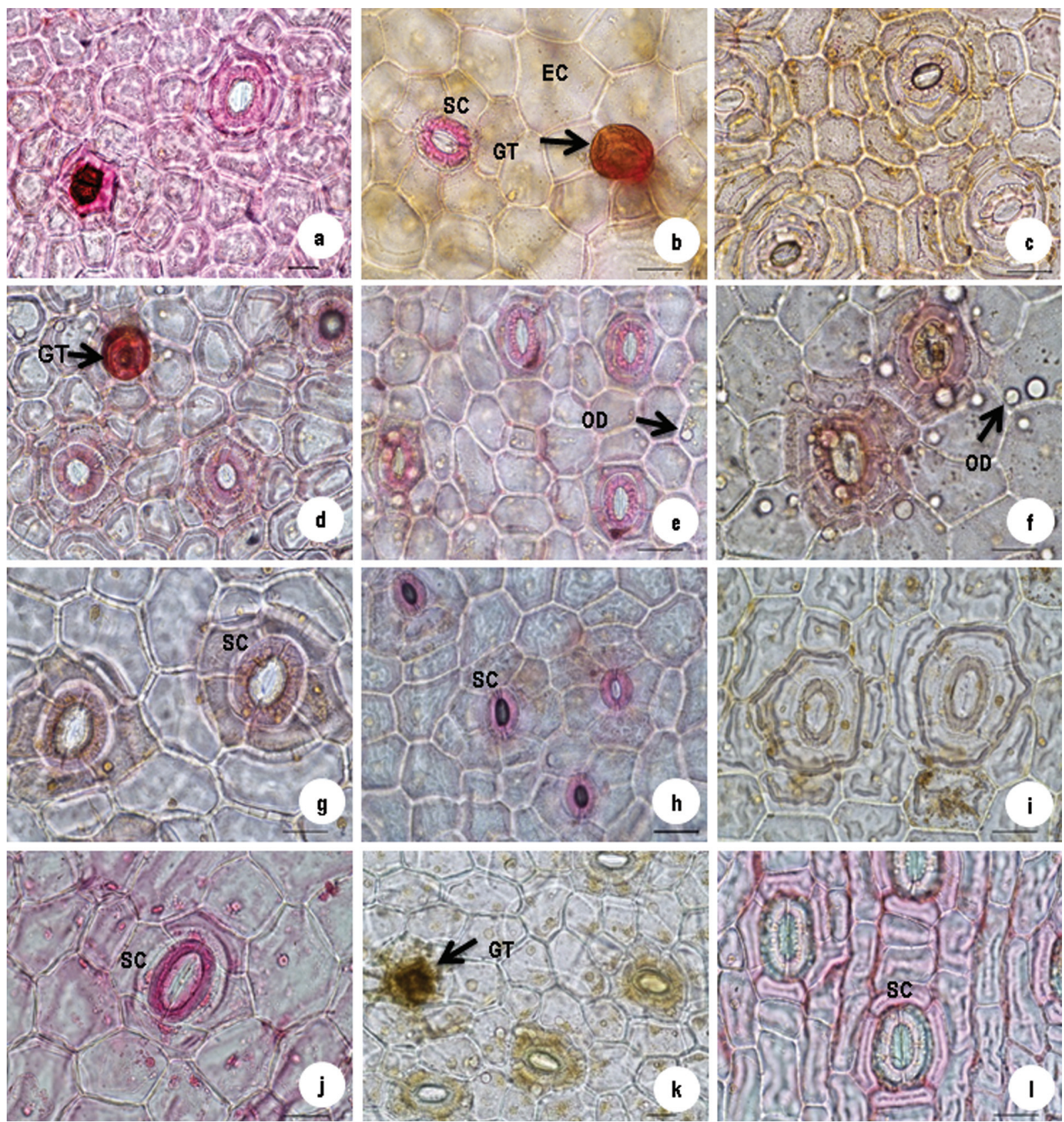

Fig. 1. Photomicrographs of Bulbophyllum Thouars. species (at 400x) showing variation in leaf (abaxial) epidermal characters epidermal cell shape and stomatal rim: a. Large epidermal cells (EC) with cuticular thickening and stoma of $B$. affine Lindl.; b. Small round stoma, subsidiary cell (SC), and glandular trichomes (GT) of B. cherrapunjeense Barbhuiya \& D.Verma; c. EC arrangement pattern and large stomata of $B$. cauliflorum Hook.f.; d. Small EC showing cuticular thickening along the inner wall of EC, small round stomata of $B$. ambrosia (Hance) Schltr.; e. EC and stoma with rim of B. gymnopus Hook.f.; f. Thin walled EC and round stoma with 4-5 subsidiary cells (SC) of B. sunipia J. Verm., Schuit. \& de Vogel; g. Large, thick walled EC, large stomatal complex with 4-5 SC of. B. striatum (Griff.) Rchb.f.; $\boldsymbol{h}$. Thin walled EC and small round stoma with 4-6 SC and cuticular thickening on the surface of $B$. leopardinum (Wall.) Lindl. ex. Wall.; i. Large EC with cuticular thickening and stomata of $B$. bisetum; j. Large thin walled EC and stoma with 4 SC of B. pteroglossum Schltr.; $\mathbf{k}$. EC, stomata and GT of $B$. umbellatum Lindl.; I. EC arranged in row and stomata with 4-5 SC. Note the cuticular thickening on EC of B. reptans (Lindl.) Lindl. ex. Wall. EC - epidermal cell; GT - glandular trichome; OD - oil droplet; SC - subsidiary cell.

epidermal cell size, as recorded from leaf transverse sections was found to be $>1.5$ in B. affine, B. ambrosia and $B$. umbellatum, around 1 in B. bisetum, $B$. cherrapunjeense, B. gymnopus and B. sunipia, $<0.77$ in B. cauliflorum, B. pteroglossum and B. striatum, and lowest in B. leopardinum (0.471) and B. reptans (0.534) (Table 3). The epidermal cell density was much higher on the abaxial surface than on the 

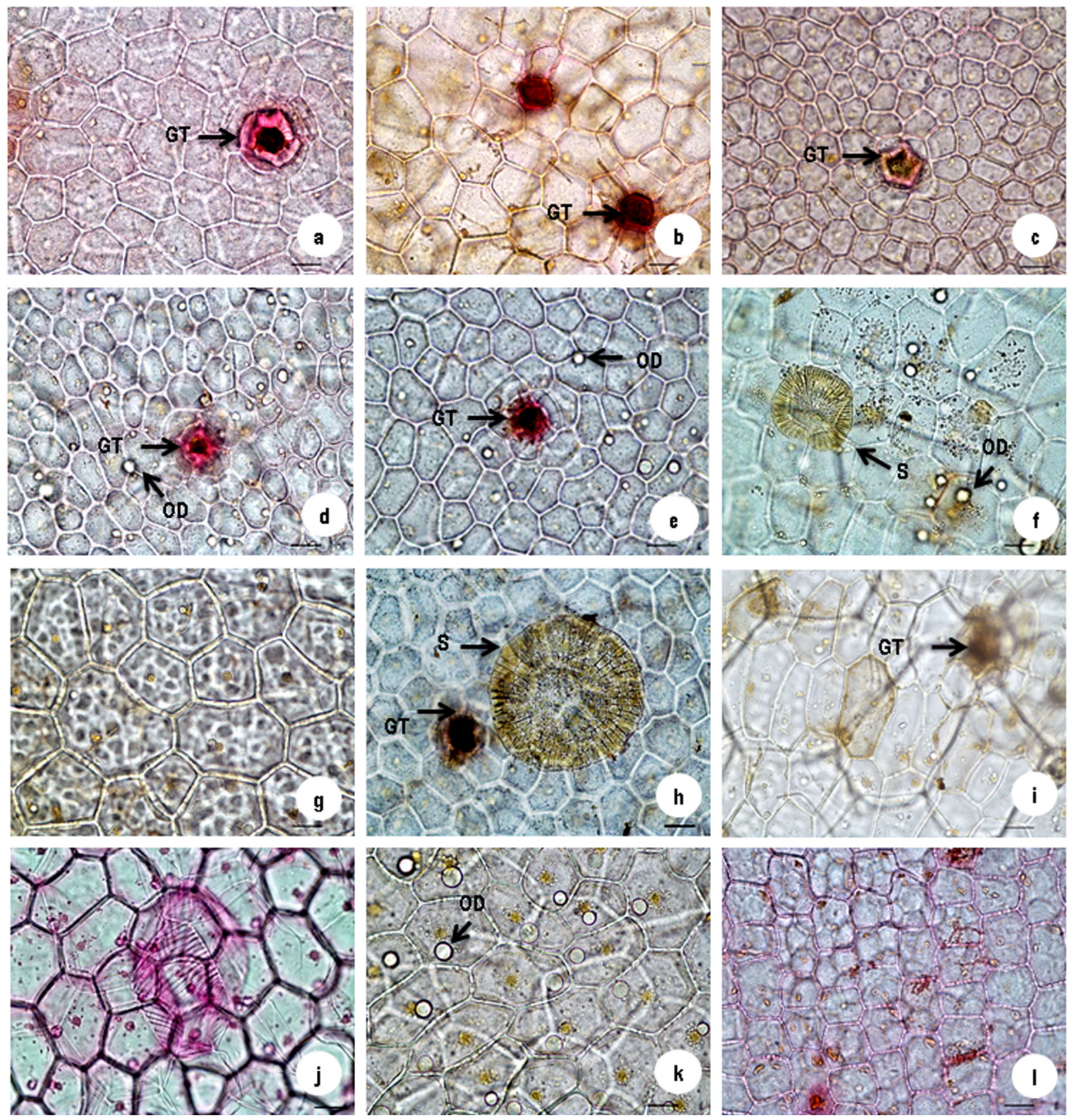

Fig. 2. Photomicrographs of Bulbophyllum Thouars. species (at $400 x$ ) showing variation in leaf (adaxial) epidermal characters: a-e, h \& i. Large thick-walled polygonal (epidermal cells) EC and glandular trichomes (GT) of a. B. affine Wall. ex. Lindl., b. B. cherrapunjeense Barbhuiya \& D.Verma, c. B. cauliflorum Hook.f., d. B. ambrosia (Hance) Schltr., e. B. gymnopus Hook.f., h. B. sunipia Verm., Schuit. \& de Vogel and i. B. leopardinum (Wall.) Lindl. ex. Wall. respectively. d-f \& h. Oil droplets (OD) in EC of B. ambrosia (Hance) Schltr., B. gymnopus Hook.f., B. sunipia Verm., Schuit. \& de Vogel and B. umbellatum Lindl. f \& h. multicellular sessile GT (scale) of f. B. sunipia Verm., Schuit. \& de Vogel and h. B. leopardinum (Wall.) Lindl. ex. Wall. respectively. g. j \& k. Large polygonal EC of B. striatum (Griff.) Rchb.f., B. bisetum Lindl. and B. umbellatum Lindl. respectively. I. EC arranged in uniseriate rows square shaped. EC - epidermal cell; GT - glandular trichome; OD - oil droplet; $S$ - scale/ sessile trichome.

adaxial leaf surface, except in B. ambrosia (Table 3). Oil droplets were observed in epidermal cells of $B$. ambrosia, B. gymnopus, B. sunipia and B. umbellatum (Figs. 1e, f \& 2d-f, k).

Stomata: The leaves of all species studied were hypostomatic, i.e. stomata were confined to the abaxial surface (Fig. 1a-1). The stomata were of the tetracytic type in all species except in B. striatum where they were of the tetracyclocytic type (Table 2). The number of subsidiary cells was variable 


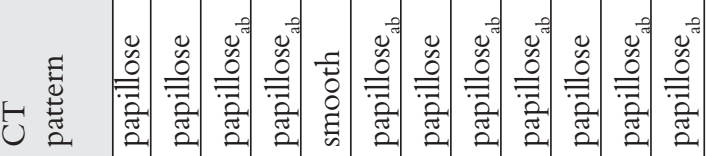

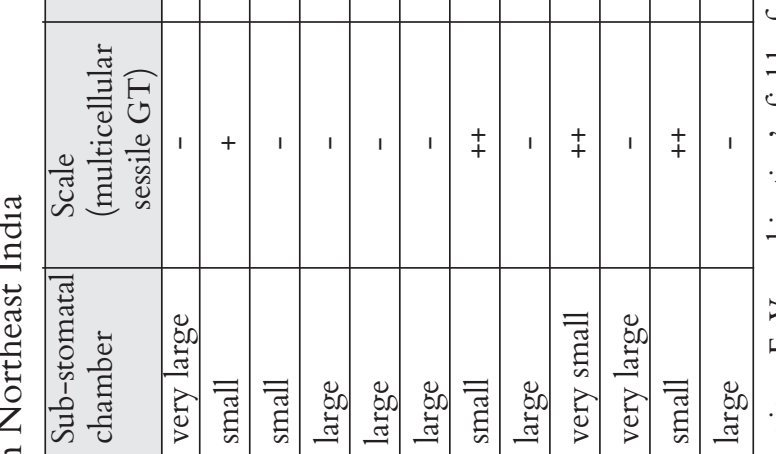

:

咅

(2)

范

.

के

I

.

岂

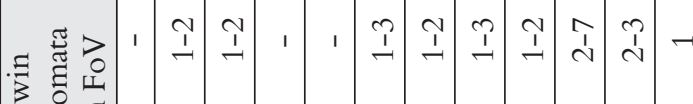

谣.

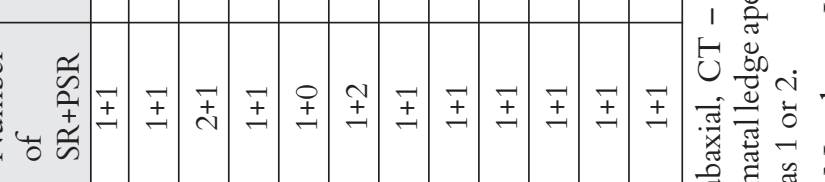

(1) 1010

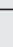

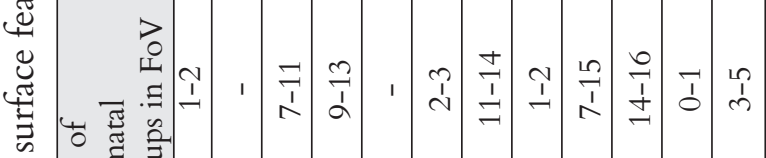

它

०ै

তี

苋

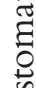

峞

药

芯

莺

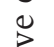

胥

$\stackrel{.5}{\circ}$

तi

$\frac{0}{\frac{\pi}{\pi}}$

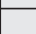

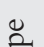

\begin{tabular}{llllllll}
\hline & & & & & & \\
\hline
\end{tabular}

䒕

号

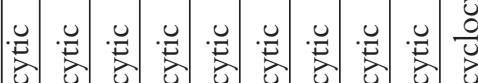

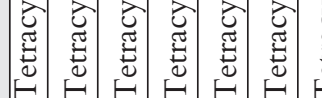


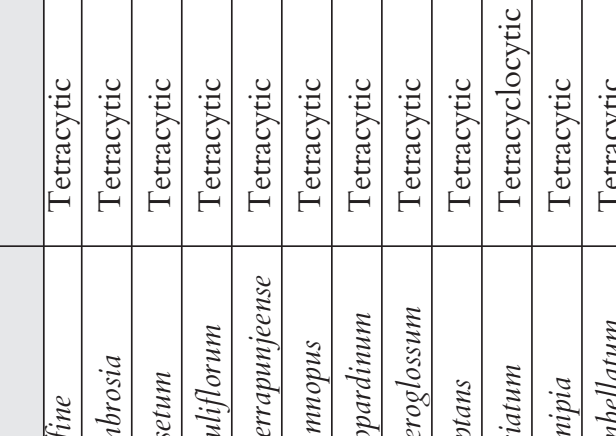

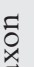

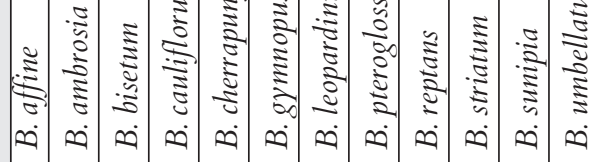

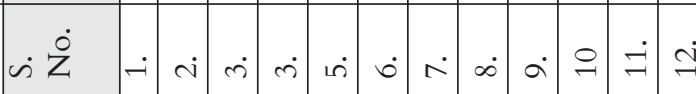

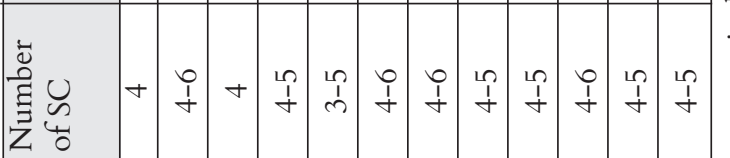

1.0

运岕这

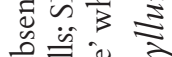

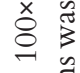

3 ह

$\begin{array}{lll}5 & \overrightarrow{0} \\ 0 & 0\end{array}$

एृ

is

$\frac{0}{4} \frac{0}{5}$

$>\frac{\pi^{3}}{1}$

施

离 $\frac{1}{\sim}$

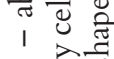

1 .

달.

焉责完

苞记

.0

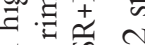

푠

节

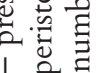

$+10$

बै चै

E 0 क

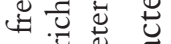

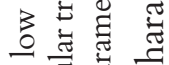

$\Xi$ 큰

苨芯矛

可

है,

100

$+\ddot{\tilde{0}}$ 。

3 焉 10

悹离苋

שี

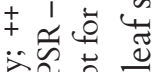

- a

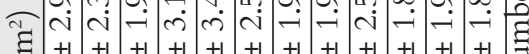

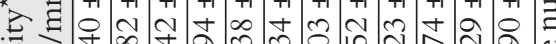

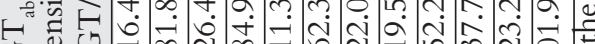
U ¿

范 *

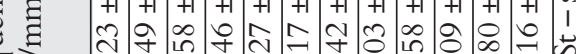

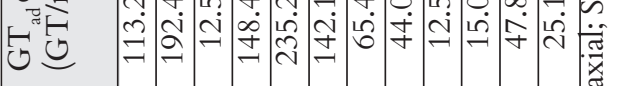

ก

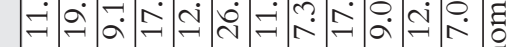

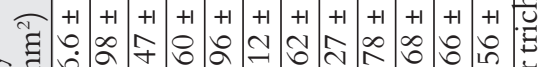
公 u.

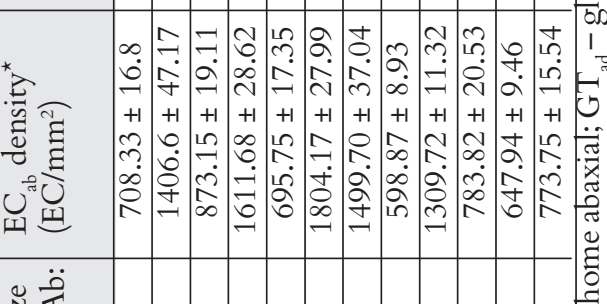

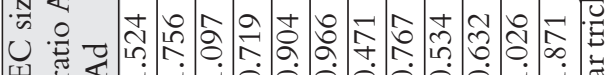

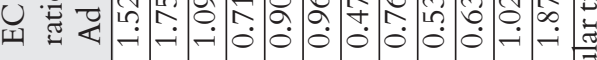
$\overline{0}$ कo

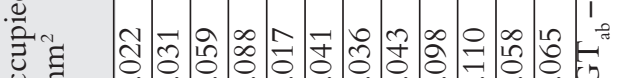

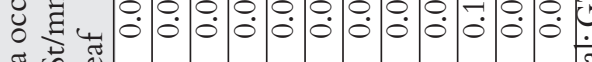

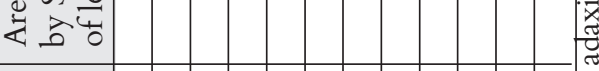

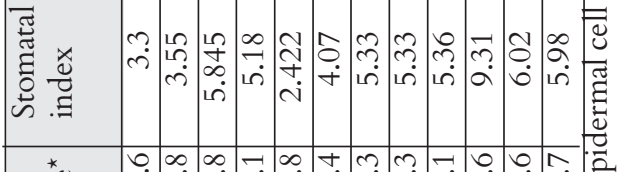

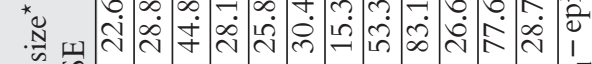

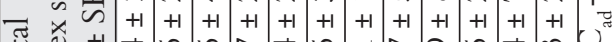

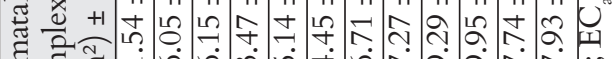

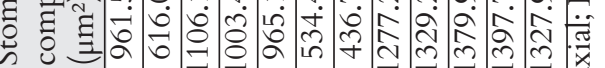

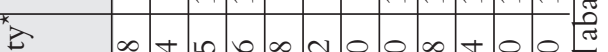

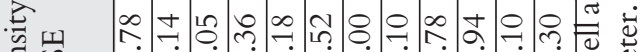

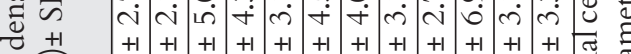

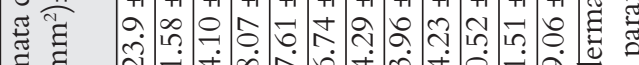

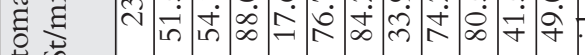
点 वे प्ष

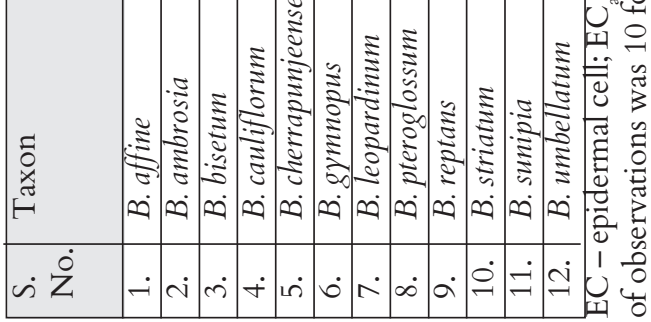


ranging from 3-6. Four subsidiary cells were observed in B. affine and B. bisetum. In others their number was variable. B. cherrapunjeense had 3-5 subsidiary cells and 4-5 were observed in $B$. cauliflorum, B. sunipia, B. pteroglossum, B. umbellatum and $B$. reptans, while for the rest of the taxa viz. $B$. ambrosia, B. gymnopus, B. striatum and B. leopardinum the number of subsidiary cells was 4-6 (Table 2).

The stomata and epidermal cells were at the same level, the sub-stomatal chambers were irregular in shape and variable in size in most species. The sub-stomatal chamber in B. affine and B. striatum was very large. Bulbophyllum cherrapunjeense, $B$. cauliflorum, B. pteroglossum, B. gymnopus and B. umbellatum had chamber sizes almost equal or slightly larger than the adjacent hypodermal cells. They were small in B. leopardinum while smallest in B. reptans. The distribution of stomata was nonuniform over the lamina and often distributed in groups (clusters) while they were distributed evenly in B. cherrapunjeense and B. ambrosia. The density of such stomatal groups per $0.079 \mathrm{~mm}^{2}$ of leaf area (i.e. the objective's field of view) ranged from $0-1$ in $B$. sunipia, $1-2$ in $B$. affine, $B$. pteroglossum, and 2-3 in B. gymnopus. The frequency of stomatal groups was distinctly high in B. striatum (14-16), B. leopardinum (11-14), B. cauliflorum (9-13) and B. reptans (7-15). Stomata that occurred in pairs, termed 'twin stomata', were not seen in B. affine, $B$. cherrapunjeense and $B$ cauliflorum. The average range of twin stomata in an objective's field of view was smallest (1) in $B$. umbellatum and larget (2-7) in B. striatum, followed by B. sunipia (2-3). In an objective's field of view, species like B. ambrosia, B. leopardinum, B. bisetum and $B$. reptans showed 1-2 twin stomata, but $B$. gymnopus and B. pteroglossum had 1-3 (Table 2). The stomatal density ranged between 17.61 and $88.07 / \mathrm{mm}^{2}$, and was lowest in $B$. cherrapunjeense and highest in $B$. cauliflorum, followed by $B$. leopardinum (84.29/. $\mathrm{mm}^{2}$ ) and B. striatum (80.52/ $\mathrm{mm}^{2}$ ) (Table 3).

The correlation coefficient values between the pairs of different surface features like the density of stomata with epidermal cell $\left(\mathrm{r}^{2}=0.5483, P<0.01\right)$, density of stomata with area occupied by the stomata per unit area of leaf $\left(\mathrm{r}^{2}=0.4114, P<0.025\right)$, and stomatal index with trichome density (adaxial and abaxial respectively $r^{2}=0.5639, r^{2}=0.5828$, $P<0.01)$ indicated significant correlations between these characters across the species. The stomatal index (SI) of B. striatum was highest (9.31) followed by B. sunipia (6.02), and B. umbellatum (5.98), whereas this value was lowest in $B$. cherrapunjeense (2.42) (Fig. 4, Table 3). The size of stomatal complexes showed a large variation ranging between $436.71 \mu \mathrm{m}^{2}$ and $1397.74 \mu \mathrm{m}^{2}$ among all species. Small complex sizes were noted in $B$. leopardinum $\left(436.71 \mu^{2}\right)$, B. gymnopus $\left(534.45 \mu \mathrm{m}^{2}\right)$ and $B$. ambrosia $\left(616.05 \mu \mathrm{m}^{2}\right)$, while medium sizes were noted in B. cherrapunjeense $\left(965.14 \mu \mathrm{m}^{2}\right)$ and B. affine $\left(961.54 \mu \mathrm{m}^{2}\right)$ (Table 3). The stomatal ledges were present in all species but the shape of the stomatal ledge aperture (SLA) was variable i.e. round, narrow round, elliptical and narrow elliptical (Table 2, Fig. 3a-j).

Trichomes: Two types of multicelular glandular trichomes i.e. sessile (Fig. 2f,h), and sunken unbranched (Figs. 1 \& 3m) were observed. Whereas, the former was present in all species, the latter was observed only in four species, namely $B$. ambrosia, B. leopardinum, B. reptans and B. sunipia (Fig. 2). The density of sunken trichomes on both surfaces showed vast variation between the species, from 12.58 to 235.27 per $\mathrm{mm}^{2}$ of leaf lamina area on the adaxial, and 26.42 to 362.34 on the abaxial surface. As such, the density of these glandular trichomes was nearly double on the abaxial surface (Table 3).

Theobald et al (1979) identified these trichomes as multicellular sessile glandular trichomes (scales). These were flattened or shield-like circular structures made up of a considerable number of ray cells arising from the centre. The frequency of sessile trichomes was very low in $B$. ambrosia, $B$. reptans, while B. sunipia and B. leopardinum exhibited a high frequency (Table 2). 

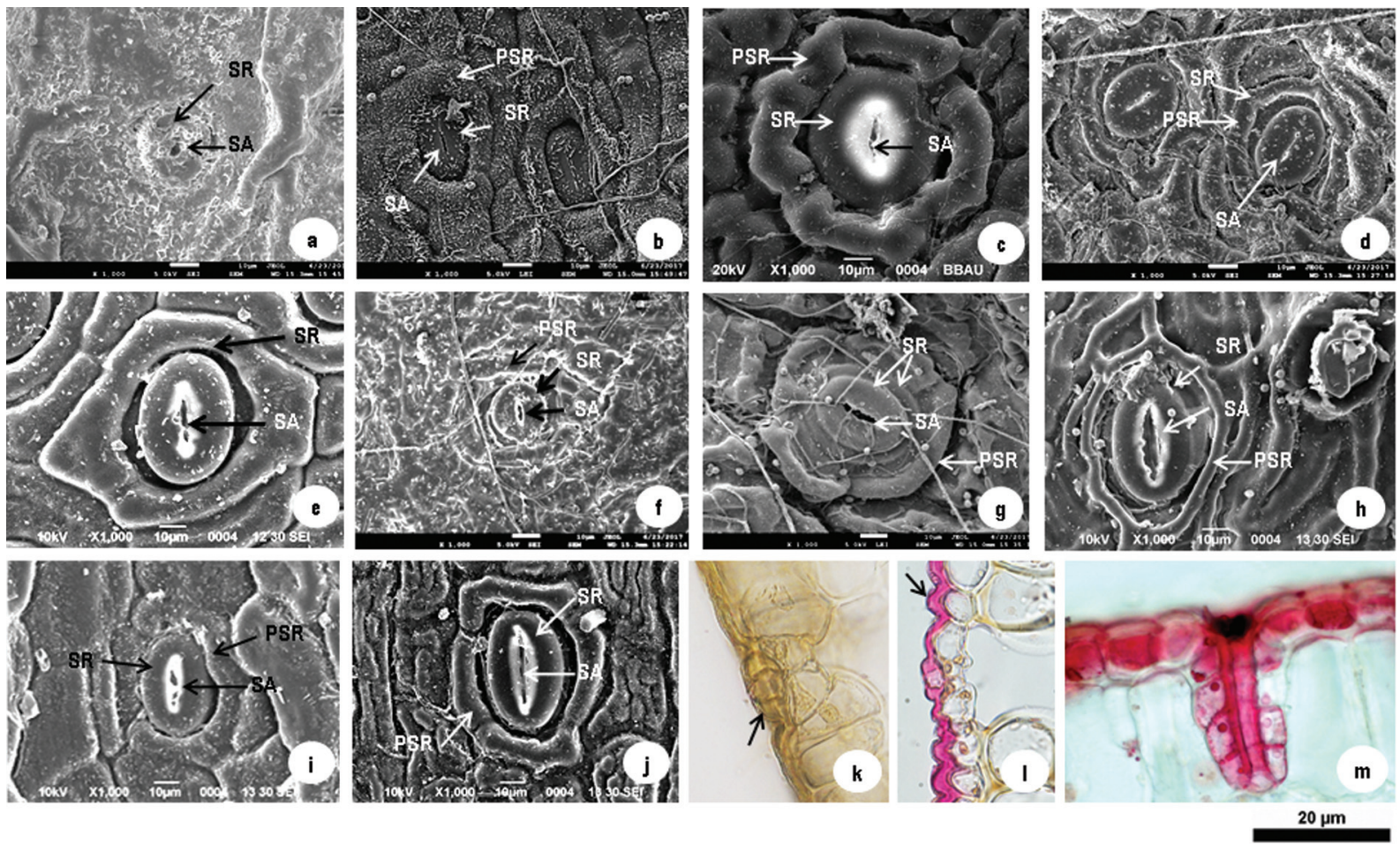

Fig. 3. Scanning electron micrographs (a-j) and transmission light microscope images (k-m) showing variation in stomatal micromorphology on the leaf surface (abaxial), cuticular pattern and sunken glandular trichome of Bulbophyllum Thouars species: a. SR and round SA in B. cherrapunjeense Barbhuiya \& D.Verma; b. B. cauliflorum Hook.f. showing single SR, PSR and narrow elliptical SA; c. B. ambrosia (Hance) Schltr. showing single SR, peristomatal rim (PSR) with narrow elliptical SA; d. B. gymnopus Hook.f. with a very narrow, tiny elliptical SA with one SR and double PSR; e. B. striatum (Griff.) Rchb.f. with single SR and PSR and narrow elliptical SA; f. B. leopardinum Schltr. showing single SR and PSR and narrow small elliptical SA; g. B. bisetum Lindl. showing two SR and one PSR; $\mathbf{h}$. B. pteroglossum Schltr. showing narrow elliptical SA, one SR and PSR; i. B. umbellatum Lindl. showing wide elliptical SA, one SR and PSR; j. B. reptans (Lindl.) Lindl. ex. Wall. showing long narrow elliptical SA, single SR and PSR; k. Smooth cuticular thickening and stomatal ledge in leaf transverse section (T.S.) of $B$. cherrapunjeense Barbhuiya \& D.Verma; I. Papillose cuticular thickening and stomatal ledge in leaf T.S. of B. gymnopus Hook. f. m. Glandular trichome of $B$. cauliflorum Hook.f. in leaf T.S. $20 \mu \mathrm{m}$ scale bar is the same for k,I and m. PSR - peristomatal rim; SA - stomatal aperture; SR -stomatal rim.

Cuticle and cuticular patterns: The leaf abaxial surfaces of the 10 species observed under SEM revealed ultrastructural details viz. cuticular thickening patterns, epicuticular wax, stomatal ledges, stomatal ledge apertures (SLA) and stomatal rims. Both surfaces of the leaves were covered with thick cuticles. The cuticular thickening pattern was papillose in B. affine, B. ambrosia, B. striatum and B. leopardinum on both surfaces, whereas in $B$. gymnopus (Fig. 31), B. cauliflorum, B. sunipia, and B. bisetum, B. pteroglossum, B. umbellatum and B. reptans it was papillose only on the abaxial surface and smooth in B. cherrapunjeense (Table 2). Epicuticular wax deposition was observed on the abaxial surface of all species except B. affine and B. sunipia (Fig. $3 a-j)$.
The cuticular folding outlined around stomata were like a rim or raised ridge known as stomatal rim. Similar folding of the cuticle was observed around stomata (Fig. 3a-j, Table 2). There was one stomatal rim in ten of the examined species with the exception of B. bisetum where there were two (Fig. $3 \mathrm{~g})$. Similarly, there was just one peristomatal rim in all species examined, except B. grmnopus which had two (Fig. 3d). In transverse sections, the leaf cuticular folding exhibited a raised appearance above the guard cells like an incomplete roofed dome termed stomatal ledge (Fig. 3k). The stomatal rim arched over the pore by forming an aperture or slit which confers a specific shape and opened into the outer stomatal ledge, named 'stomatal ledge aperture' (SLA). The SLA displayed either elliptical or round shape with slight variation (Table 2). The 
SLA shape was elliptical in B. affine, B. striatum, $B$. pteroglossum, B. umbellatum and B. reptans while narrow elliptical in B. cauliflorum, B. gymnopus and $B$. bisetum and round in B. cherrapunjeense and $B$. sunipia while narrowly round in B. ambrosia and $B$. leopardinum (Fig. 3a-j).

\section{Discussion}

Reports on morphology and vegetative anatomy of more than a dozen species of Bulbophyllum from other parts of the world are available, but studies on leaf epidermal features of species of this genus from India has largely remained elusive. The present study fills this gap to some extent and underscore the significance of leaf surface features as potential adjunct taxonomical parameters for species identification and delineation of inter-specific affinities.

The detailed account on qualitative and quantitative leaf epidermal features of the twelve epiphytic species of Bulbophyllum here could be taken as useful primer for their use to aid species identification. The leaf of $B$. affine, $B$. cherrapunjeense, B. ambrosia and B. striatum are succulent and thick, but in other species the leaves are thin, although succulent to some extent. Leaf succulence is reported as an adaptation for dry condition (Hsiao, 1973; Lack \& Evans, 2001; Metusala et al., 2017). The range of stomatal density obtained in the present study (17.61$88.07 / \mathrm{mm}^{2}$ ) was in line with the range obtained for diverse other orchids by Singh and Singh (1974; i.e., $40-110 / \mathrm{mm}^{2}$ ), and Avadhani et al. (1982; i.e., $\left.8-180 / \mathrm{mm}^{2}\right)$. Leaf succulence and stomatal density are inversely related in orchids (Goh et al., 1977). This is consistent with our observations on B. cherrapunjeense and B. affine, both have comparatively low stomatal density and succulent leaf therefore may be better adapted to xerophytic condition than other species. Piazza et al. (2015) based on the examination of cuticle thickness in 13 species suggested that this character may be useful in sectional delimitation of the species in the genus Bulbobhyllum.
The leaves of all species examined are hypostomatic (Table 2); similar to 13 other Bulbophyllum species analyzed by Piazza et al. (2015).

This is found to be a predominant condition mostly in mesophytic orchids and most other plants. It is suggested that this condition conserves water in epiphytes by significantly decreasing water loss through the aerial parts whereas in non-epiphytic plants supply of water is not intermittent (Möbius, 1887; Lavarack, 1971; Williams, 1979). In the present study two types of stomata, i.e., tetracytic and tetracyclocytic, were identified. The latter type was observed only in B. striatum. The tetracytic type was reported in B. odoratissimum (Sm.) Lindl. ex Wall. by Singh and Singh (1974) and for the one species of Bulbophyllum studied by Williams (1979). The cyclocytic type of stomata were reported in few species of Bulbophyllum by Kaushik (1983) and Rao and Khasim (1987). Likewise, occurrence of variation in number of subsidiary cells between the species has the potential for taxonomic differentiation and deducing interspecific evolutionary relationship, e.g., B. cherrapunjeense, $B$. affine and B. bisetum can be identified based on the number of subsidiary cells. Rao and Khasim (1987) reported 4-7 subsidiary cells in three species of Bulbophyllum including B. leopardinum with 4-6 subsidiary cells. Although, Stebbins and Khush (1961) and Withner et al. (1974) reported that Orchidaceae lacked subsidiary cells. However, some authors on the other hand reported the presence of subsidiary cells in Vanilla (Roux, 1954; Rosso, 1966) of in subfamily Cypripedioideae. The species $B$. leopardinum, B. gymnopus and B. ambrosia may be comparatively better adapted to draught conditions, since Guan et al. (2011) revealed an inverse relationship between stomata size and adaptation to drought condition in other orchid genera. However, empirical studies are needed to confirm whether this hypothesis holds for Bulbophyllum. Species like B. leopardinum, B. cherrapunjeense, B. sunipia and B. striatum have large epidermal cells on both the surfaces that play roles in water storage in other orchid genera (Guan et al., 2011). Santhosh 


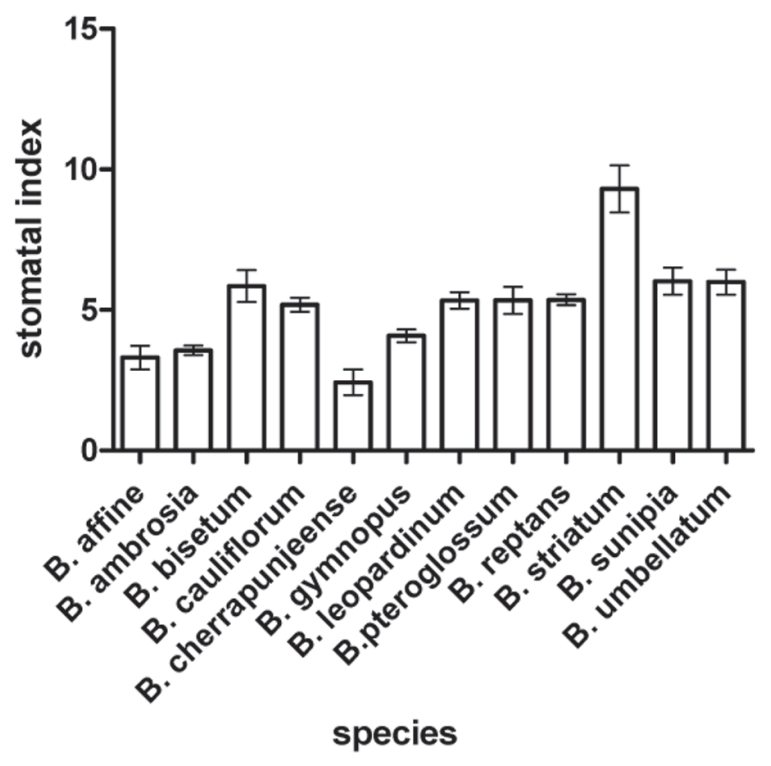

Figure 4. Stomatal index (means $\pm \mathrm{SE}$ ) of Bulbophyllum species, i.e. the percentage of stomata in relation to epidermal cells on the abaxial epidermal surface.

et al. (2015) reported on the dependence of stomatal characters on environmental conditions rather than genetic factors. However, some stomatal features observed in Bulbophyllum species viz. stomatal aperture shape, stomatal rim number and substomatal chamber size may be used to understand their taxonomic significance. Stomata have significant roles in the physiology, evolution and ecology of plants (Hetherington \& Woodward, 2003). A positive correlation between stomatal index (SI) and glandular trichomes density on the abaxial $\left(\mathrm{r}^{2}=0.5828, P<0.01\right)$ and adaxial $\left(\mathrm{r}^{2}=0.5639\right.$, $P<0.01)$ surface was found in the present study.

The presence of a leaf cuticle is a very common feature of epiphytic orchids. The cuticular thickening pattern was smooth in B. cherrapunjeense whereas in other species papillose cuticles were observed which is an important diagnostic feature (Table 2) (Pridgeon, 1993). According to Haworth and McElwain (2008) and Yang et al. (2016) thick cuticles in epiphytic orchid leaves revealed the adaptation to tolerate extreme arid conditions. Stomatal ledges form an opening on the surfaces of leaves which can have variable shapes in all species. The stomatal ledge was previously reported in some species of Bulbophyllum by Sprenger (1904) and in orchids by Rasmussen (1987). B. gymnopus and B. affine exhibited characteristic numbers of stomatal rims, i.e., 1-3 and 2 respectively (Moore et al., 2010). The leaf epidermal characters examined in this study viz. thick and papillose cuticular thickening, smaller stomata, sub-stomatal chamber, stomatal ledge, large epidermal cells, mucilage secreting glandular trichomes and stomatal rim indicate that the species appears to be variably adapted to their ecological niche. Rasmussen (1987) recognized them as xeromorphic characters. A fairly high number of stomata per unit area and their occurrence in groups (clusters) could be considered as an attribute to their micro-environment. Rao and Khasim (1987) observed twin stomata in B. leopardinum. The stomatal ledges were present in all species. Yukawa et al. (1992) discussed the stomatal ledge in Dendrobium and reported the shape of stomatal ledge as important taxonomic marker. The presence of large sub-stomatal chambers in B. affine, B. striatum, B. pteroglossum and B. umbellatum is the water conserving attribute in these species. The sunken glandular trichomes are found in abundance on both leaf surfaces. Rao and Khasim (1987) identified them as 'absorbing trichomes' and Oliveira and Sajo (1999) also observed absorbing trichomes in orchid species. The occurrence of two types of glandular trichomes, variation in their morphological forms and density are important for providing taxonomic relationships.

The trichome types and their structure could be used as parameter for species identification (Seithe, 1979; Lavania, 1990). The diversity in glandular trichomes indicated adaptation towards their microclimate (Pridgeon, 1982; Pridgeon \& Stern, 1982; Kaushik, 1983; Rao \& Khasim, 1987; Isaiah $\&$ Rao, 1992). Occurrence of oil droplets in abaxial and adaxial epidermal cells could be another microtaxonomic parameter. Pridgeon et al. (2014) reported taxonomic significance of oil droplets in epidermal cells of Bulbophyllum species.

Beside epidermal features, here we provide useful information on the deposition of epicuticular wax 
on the abaxial surface of leaf as examined by scanning electron microscopy, and the due identification of epicuticular wax according to Barthlott et al. (1998). This is the first report for the genus Bulbophyllum that can be used to supplement species characterization since wax morphotypes have significance in species delineation (Barthlott et al., 1998).

In the present study eight dermal characters were considered as taxonomic marker for species differentiation in Bulbophyllum: (1) hypostomaty; (2) number of subsidiary cells; (3) stomatal rim; (4) shape of stomatal ledge; (5) cuticular thickening pattern of leaf abaxial surface; (6) the type of epicuticular wax; (7) glandular trichomes (sunken trichomes and scales) and (8) stomata type. There were nine putative adaptive features observed in leaf dermal micromorphology of this genus: (1) leaf succulence, (2) reduced stomatal density, (3) low stomatal index (Fig. 4), (4) reduced stomata size, (5) high trichome density, (6) presence of stomatal ledge, (7) large sub-stomatal chamber, (8) hypostomaty, and (9) large epidermal cells. The presence of these features in the Bulbophyllum species studied here may support their ecological adaptation to the harsh conditions they are exposed to since these plants grow on the bark of trees or rocks. However, empirical studies are required to confirm their significance in this hypothesis.

\section{Conclusion}

The leaf dermal characters studied in the present study of 12 Bulbophyllum species were found to have potential taxonomic significance. The stomatal traits, glandular trichome type, their distribution and cuticular thickening pattern were potentially valuable for characterization and differentiation of the species. However, the tetracytic type of stomata is the most common type in the genus, and thus is of limited use for the taxonomy of the genus. Interspecific variations in these dermal features could help to identify species like B. cherrapunjeense, B. striatum, B. leopardinum,
B. gymnopus and B. bisetum. The distinct arrangement of epidermal cells in Bulbophyllum reptans is useful for this species's characterization. Such an outcome from the present study would be useful as taxonomic marker between the species in the genus and genera within the family.

The epicuticular wax deposition, presence of multicellular sessile glandular trichomes (scales) on the dermal surfaces of leaves are reported for the first time for the genus Bulbophyllum. Further studies on the morphological variations of these epicuticular waxes would be important to understand the role in species characterization. Structural biochemical studies of wax components would help to understand its physiological functions, potential role in adaptation towards the varied environmental conditions the plants encounter. Further studies involving more species could provide more reliable and forceful criteria to ascertain the reliability of leaf epidermal characters as diagnostic features, and to develop micromorphological taxonomic keys for the genus.

\section{Acknowledgements}

Authors are grateful to the Head of the Office, Botanical Survey of India, Eastern Regional Centre, Shillong for providing facilities during collection; Babasaheb Bhimrao Ambedkar University, Lucknow for Scanning Electron Microscopy. This work was partially funded by the CSIR Emeritus Scientist Scheme No.21(1106)/20/EMR-II to SL.

\section{Literature Cited}

ADEDEJI O. \& O.A. JEWOOLA 2008. Importance of leaf epidermal characters in the Asteraceae family. Notulae Botanica Horti Agrobotanici Cluj-Napoca 36(2): 7-16.

AGBAGWA I.O. \& B.E. OKOLI 2006. Leaf epidermal micromorphology in the systematics of Abrus (Papilionaceae) in parts of tropical West Africa. Asian Journal of Plant Science 5: 41-49. https://doi.org/10.3923/ ajps.2006.41.49

AHMAD K.J. 1964. Epidermal studies in Solanum. Lloydia 27: 165-177.

ARDITTI J. 1992. Fundamentals of Orchid biology. John Wiley \& Sons, New York. 
AREVALO R., FIGUEROA J. \& S. MADRINAN 2011. Anatomía foliar de ocho especies de Orquídeas epífitas. Lankesteriana 11(1): 39-54. (in Spanish, with English abstract)

ATWOOD J. 1986. The size of the Orchidaceae and the systematic distribution of epiphytic orchids. Selbyana 9: 171-186.

AUGUSTINE J., KUMAR Y. \& J. SHARMA 2001. Orchids of India-II: biodiversity and status of Bulbophyllum Thou. Daya Publishing House, Delhi.

AVADHANI P.N., GOH C.J., RAO A.N. \& J. ARDITTI 1982. Carbon fixation. In: ARDITTI J. (ed.), The Orchid biology: reviews and perspectives II. Cornell University Press, NewYork. pp. 173-193.

AYBEKE M., SEZIKI E. \& G. OLGUN 2010. Vegetative anatomy of some Ophrys and Dactylorhiza (Orchidaceae) taxa in Trakya region of Turkey. Flora 205(2): 73-89. https://doi.org/10.1016/j.flora.2008.11.009

AYODELE A.E. \& J.D. OLOWOKUNDEJO 2006. The family Polygonaceae in West Africa: taxonomic significance of leaf epidermal characters. South African Journal of Botany 72: 442-459. https://doi.org/10.1016/ j.sajb.2005.12.009

BARANOVA M. 1972. Systematic anatomy of the leaf epidermis in the Magnoliaceae and some related families. Taxon 21(4): 447-469. https://dx.doi.org/10.2307/ 1219106

BARANOVA M. 1992. Principles of comparative stomatographic studies of flowering plants. Botanical Review 58: 49-99.

BARTHLOTT W. 1981. Epidermal and seed surface characters of plants: systematic applicability and some evolutionary aspects. Nordic Journal of Botany 1(3):345$355 . \quad$ https://doi.org/10.1111/j.17561051.1981.tb00704.x

BARTHLOTT W., NEINHUIS C., CUTLER D., DITSCH F., IRIS M., THEISEN I. \& H. WILHELM 1998. Classification and terminology of plant epicuticular waxes. Botanical Journal of Linnean Society 126(3): 237-260. https://doi.org/10.1111/j.10958339.1998.tb02529.x

BLANCO M.A., DAVIES K.L., STPICZYN'SKA M., CARLSWARD B.S., IONTA G.M. \& G. GERLACH 2013. Floral elaiophores in Lockhartia Hook. (Orchidaceae: Oncidiinae): their distribution, diversity and anatomy. Annals of Botany 112(9): 1775-1791. https://doi.org/10.1093/aob/mct232

CARLQUIST S. 1961. Comparative plant anatomy. Holt, Rinehart and Winston, New York.
CARLSWARD B.S., STERN W.L., JUDD W.S. \& T.W. LUCANSKY 1997. Comparative leaf anatomy and systematics in Dendrobium, Section Aporum and Rhizobium (Orchidaceae). International Journal of Plant Science 158(3): 332-343. https://thekeep.eiu.edu/bio_fac/ 260

CHASE M.W., PRIDGEON ALEC M., BERG C.V.D., GOLDMAN D.H., FREUDENSTEIN J.V. \& K.M. CAMERON 2005. An overview of the phylogenetic relationships within Epidendroideae inferred from multiple DNA regions and re-circumscription of Epidendreae and Arethuseae (Orchidaceae). American Journal of Botany 92(4): 613-624. https://doi.org/ 10.1093/aob/mcu253

CHATIN A. 1856. Anatomie des plantesaériennes de l'ordre des Orchidées. 1 Memoire: anatomie des racine. Mémoires de la Société Imperiale Académique de Cherbourg 4: 5-18.

CUTLER D.F. 1979. Leaf surface studies in Aloe and Haworthia species (Liliaceae): taxonomic implications. Tropische und Subtropische Pflanzenwelt 28: 449-471.

DAS S. \& N. PARIA 1992. Stomatal structure of some Indian orchids with reference to taxonomy. Bangladesh Journal of Botany 21(1): 65-72.

DAVIES K.L. \& M. STPICZYÑSKA 2014. Labellar anatomy and secretion in Bulbophyllum Thouars (Orchidaceae: Bulbophyllinae) sect. Racemosae Benth. \& Hook.f. Annals of Botany 114: 889-911. https:// doi.org/10.1039/aob/mcu153

DRESSLER R.L. 1981. The Orchids: natural history and classification. Harvard University Press, Cambridge.

DRESSLER R.L. 1993. Phylogeny and classification of Orchid family. Press Syndicate, University of Cambridge.

FAHN A. 1979. Secretory tissues in plants. Academic Press, New York \& London.

FAN J., HE R., JHANG Y. \& X. ZING 2014. Systematic significance of leaf epidermal features in Holcoglossum (Orchidaceae). PloS ONE 9(7): e101557. https://doi.org/ 10.1371/journal.pone.0101557

FISCHER G.A., GRAVENDEEL B., SIEDER A., ADRIANTIANA J., HEISELMAYER P., CRIBB P. J., SMIDT E.C., SAMUEL R., M. KIEHN 2007. Evolution in resupination of Malagasy species of Bulbophyllum (Orchidaceae). https://doi.org/10.1016/j.ympev.2007. 06.023

GILANI S.S., KHAN M.A., SHINWARI Z.K. \& Z. YOUSAF 2002. Leaf epidermal anatomy of selected Digitaria species, tribe Paniceae, family Poaceae of Pakistan. Pakistan Journal of Botany 34: 257-273.

GOH C.J., AVADHANI P.N., LOH C.S., MANEGRAFF C. \& J. ARDITTI 1977. Diurnal stomatal and acidity 
rhythms in Orchid leaves. New Phytologist 78: 365-372. https://doi.org/10.1111/j.1469-8137.1977.tb04840.x

GUAN Z.J., ZHANG S.B., GUAN K.Y., LI S.Y. \& H. HONG 2011. Leaf anatomical structure of Paphiopedilum and Cypripedium and their adaptive significance. Journal of Plant Research 124: 289-298. https://doi.org/10.1007/s10265-010-0372-z

HÁGSATER E., SOTO ARENAS M. Á., SALAZAR CHÁVEZ G. A., JIMÉNEZ MACHORRO R., LÓPEZ ROSAS M.A. \& R.L. DRESSLER 2005. Orchids of Mexico. Productos Farmaceuticose, Mexico City. (in Spanish) https://doi.org/10.21829/abm75.2006.1132

HAWORTH M. \& M. MCELWAIN 2008. Hot, dry, wet, cold or toxic? Revisiting the ecological significance of leaf and cuticular micromorphology. Palaeogeography, Palaeoclimatology, Palaeoecology 262:79-90. https:// doi.org/10.1016/j.palaeo.2008.02.009

HETHERINGTON A.M. \& F.I. WOODWARD 2003. The role of stomata in sensing and driving environmental change. Nature 424: 901-908. https:// doi.org/10.1038/nature01843

HICKEY L.J. 1973. Classification of the architecture of dicotyledonous leaves. American Journal of Botany 60(1): 17-33. http://www.jstor.org/stable/2441319

HOSSAIN M.M. 2011. Therapeutic orchids: traditional uses and recent advances - an overview. Fitoterapia 82(2): 102-140. https://doi.org/10.1016/j.fitote.2010.09.007

HSIAO T.C. 1973. Plant responses to water stress. Annual Review of Plant Physiology 24: 519-570. https://doi.org/ 10.1146/annurev.pp.24.060173.002511

INAMDAR J.A. 1970. Epidermal structure and development of stomata in some Polygonaceae. Proceedings of Indian Academy of Sciences 72(2): 91-98. https://doi.org/ 10.1007/BF03051743

ISAIAH J.M. \& P.R.M. RAO 1992. Vegetative anatomy of Dendrobium jenkinsii Wall. ex Lindl. Journal of Orchid Society of India 6(1,2): 63-69.

JOHANSEN D.A. 1940. Plant microtechnique McGraw-Hill Book Company Inc., New York \& London.

JONES D.L. 1988. Native orchids of Australia. Reed Books, Frenchs Forest, New South Wales.

KATAKI S.K. 1986. Orchids of Meghalaya. Government of Meghalaya, Shillong.

KAUSHIK P. 1983. Ecological and anatomical marvels of the Himalayan orchids. Today and Tomorrow's Printers \& Publishers, New Delhi.
LACK A.J. \& D.E. EVANS 2001. Instant notes on plant Biology. BIOS Scientific Publishers Limited, Oxford.

LAVANIA S. 1990. Trichome morphology in Indian Solanum. Journal of Indian Botanical Society 69: 143-148.

LAVARACK P.S. 1971. The taxonomic affinities of the Neottioideae. Ph.D. thesis, University of Queensland.

LUO Y. \& Z.K. ZHOU 2001. Leaf epidermis of Quercus L. subgenus Cyclobalanopsis (Oerst.) Schneid. (Fagaceae). Acta Phytotaxonomica Sinica 39: 489-501. (in Chinese)

MEHRA P.N. \& S.P. VIJ 1974. Some observations on ecological adaptations and distribution pattern of the east Himalayan Orchids. American Orchid Society Bulletin 43: 301-315.

METCALFE C.R. 1960. Anatomy of Monocotyledons. 1. Gramineae. Clarendon Press, Oxford University, New York.

METCALFE C.R. 1961. The anatomical approach to systematic. General introduction with special reference to recent work on monocotyledons. Recent Advances in Botany 146-150.

METCALFE C.R. \& L. CHALK 1950. Anatomy of the Dicotyledons. publisher New York.

METUSALA D., SUPRIANTNA J., NISYAWATI \& D. SOPANDIE 2017. Comparative leaf and root anatomy of two Dendrobium species (Orchidaceae) from different habitat in relation to their potential adaptation to drought. AIP Conference Proceedings 1862: 030118. https://doi.org/10.1063/1.4991222

MISRA S. 2007. Orchids of India: a glimpse. Bishen Singh Mahendra Pal Singh, Dehra Dun.

MÖBIUS E.P. 1887. Über den anatomischen Bau der Orchieenblätter und dessen Bedeutung für das System dieser Familie. Jahrbücher für Wissenschaftliche Botanik 18: 30-607.

MOORE B.R., MOORE T. \& N.A. NARKKONG 2010. A preliminary systematic analysis of epidermal characters for six Smilax species in Thailand. Science Asia 36: 175179. https://doi.org/10.2306/scienceasia15131874.2010.36.175

MULGAONKAR M.S. 2005. Studies on dermal anatomy of three corticolous orchids from India. International Journal of Mendel 22(3-4): 105-106. http://dspace. vpmthane.org:8080/jspui/bitstream/123456789/2096/3/ i-11.pdf

MUTHUKUMAR T. \& M. SHENBAGAM 2018. Vegetative anatomy of the orchid Bulbophyllum sterile (Orchidaceae: Epidendroideae) Lankesteriana 18(1): 1322. https://doi.org/10.15517/lank.v18i1.32701 
NUNES E.L.P., SMIDT E.C., STÜTZEL T. \& A. IKE COAN 2014. What do floral anatomy and micromorphology tell us about Neotropical Bulbophyllum section Didactyle (Orchidaceae: Bulbophyllinae)? Botanical Journal of the Linnean Society 175: 438-452. https://doi.org/10.1111/boj.12176

OGUNKUNLE A.T.J. 2013. The value of leaf epidermal characters in diagnosing some Nigerian species of Ficus L. (Moraceae). Research Journal of Botany 8(1): 1-14. https://doi.org/10.3923/rjb.2013.1.14

OLIVEIRA V.D.C. \& M.G. SAJO 1999. Anatomia foliar de espécies epífitas de Orchidaceae. Revista Brasileira de Botanica 22(3): 365-374. (in Portuguese with English Abstract)

OLIVER W.R.B. 1930. New Zealand Epiphytes. Journal of Ecology 18(1): 1-50. https://doi.org/10.2307/2255890

PIAZZA L.D., SMIDT E.C. \& BONA 2015. Anatomia comparada dos órgãos vegetativos de espécies de Bulbophyllum seção Didactyle (Lindl.) Cogn. E Bulbophyllum seção Xiphizusa Rchb.f. (Orchidaceae). Hoehnea 42(1): 171-183. (in Portuguese with English Abstract). https://doi.org/10.1590/2236-8906-34/2014

PRIDGEON A.M. 1982. Diagnostic anatomical characters in the Pleurothallidinae (Orchidaceae) American Journal Botany 69(6): 921-938.

PRIDGEON A.M. 1986. Anatomical adaptations in Orchidaceae. Lindleyana 1: 90-101.

PRIDGEON A.M. 1993. Systematic leaf anatomy of Caladenia (Orchidaceae). Kew Bulletin 48(3): 533-543.

PRIDGEON A.M. \& N.H. NORRIS 1979. Anatomical aspects of Dresslerella (Orchidaceae). Selbyana 5(2): 120134.

PRIDGEON A.M. \& W.L. STERN 1982. Vegetative anatomy of Myoxanthus (Orchidaceae). Selbyana 7(1): 55-63. https://journals.flvc.org/selbyana/article/view/ 120649

PRIDGEON A.M., CRIBB P.J., CHASE M.W. \& F.N. RASMUSSEN 2014. Genera Orchidacearum. Volume 6. Epidendroideae (Part 3). Oxford University Press, Oxford.

RAO M.P.R. \& S.M. KHASIM 1986. Leaf anatomy in relation to ecological adaptability of some Himalayan orchids. Journal of the Swamy Botany Club 3: 9-13.

RAO M.P.R. \& S. M. KHASIM 1987. Anatomy of three species of Bulbophyllum (Orchidaceae) with comments on their ecological adaptability and taxonomy. Proceedings of Indian Academy of Science (Plant Science) 97(5): 391-397. https://doi.org/10.1007/BF03053565

RASMUSSEN H. 1987. Orchid stomata - structure differentiation, function, and phylogeny. In: ARDITTI J. (ed.), Orchid Biology Reviews and Perspectives. Cornell University Press, New York. pp. 105-138.

REN B., ZHU X.Y. \& Y.C. JIANG 2007. Systematic significance of leaf epidermal features in Apios and Cochlianthus (Leguminosae). Acta Phytotaxonomica Sinica 45: 274-284.

RINDIYASTUTI R., ABIWIJAYA I.K., RAHADIANTORO A., HAPSARI L. \& S. NURFADILAH 2018. Leaf anatomical characters of four epiphytic orchids of Sempu Island, East Java, Indonesia: the importance in identification and ecological adaptation. Biodiversitas 19(5): 1906-1918. https://doi.org/10.13057/biodiv/d190543

ROSSO S.W. 1966. The vegetative anatomy of the Cypripedioideae (Orchidaceae). Journal of Linnean Society (Botany) 59: 309-341. https://doi.org/10.1111/ j.1095-8339.1966.tb00066.x

ROUX P. 1954. Etudes morphologiques et histologiques dans le genre Vanilla. In: BOURIQUET G. (ed.). Le vanillier et la vanilledans le monde. Encyclopedie Biologique. XLVI. Paris. pp. 746-748.

SAHEED S.A. \& H.C. ILLOH 2010. A taxonomic study of some species in Cassiinae (Leguminosae) using leaf epidermal characters. Notulae Botanicae Horti Agrobotanici Cluj-Napoca 38(1): 21-27. https://doi.org/ 10.15835/nbha3813490

SAITO K. 2006. Mysterious ecological system in orchids. In: SAITO K. (ed.), picture book of mysterious orchids in the world. Seibundo-Shinkosha, Tokyo (in Japanese). pp. 16-40.

SANTHOSH N.R., PRASHANTHA KUMAR H.G., KRISHNASWAMY K. \& G.F.D. SOUZA 2015. A study on stomatal complex and phenology of certain epiphytic orchids of Western Ghats of Karnataka. World Journal of Pharmacy and Biotechnology 2(1): 08-13. http:/ /www.pharmaresearchlibrary.com/wp-content/ uploads/2016/03/WJPBT2596.pdf

SEBERG O., PETERSEN G., DAVIS J.I., PIRES J.C., STEVENSON D.W. \& M.W. CHASE 2012. Phylogeny of the Asparagales based on three plastid and two mitochondrial genes. American Journal of Botany 99: 875-889. https://doi.org/10.3732/ajb.1100468

SEHGAL R.N. \& P.N. MEHRA 1984. Distribution pattern of orchids in Khasi and Jaintia Hills. Indian Journal of Forestry 7: 114-119.

SEITHE A. 1979. Hair types and taxonomic characters in Solanum. In: HAWKES J.G., LESTER R.N. \& A.D. SKELDING (eds.), The biology and taxonomy of Solanaceae. Academic Press, London. pp. 307-319.

SHI J.H. \& L.Q. LI 2003. Leaf epidermal feature in Clematis 
(Ranunculaceae) with reference to its systematic significance. Acta Botanica Indica 45: 257-268.

SIEDER A., RAINER H. \& M. KIEHN 2007. CITES checklist for Bulbophyllum and allied taxa (Orchidaceae). Volume 5. Royal Botanic Gardens, Kew. https:// www.kew.org/sites/default/files/2019-02/ CITESOrchidChecklistV.pdf

SINGH V. \& H. SINGH 1974. Organization of the stomatal complex in some Orchidaceae. Current Science 43: 490-491.

SMIDT E.C., BORBA E.L, GRAVENDEEL B., FISCHER G.A. \& C. VAN DEN BERG 2011. Molecular phylogeny of Neotropical sections of Bulbophyllum (Orchidaceae) using nuclear and plastid spacers. Taxon 60: 1050-1064. https://doi.org/10.1002/ tax.604009

SOLEREDER H. \& F. MEYER 1930. Systematische anatomie der monokotyledonen. Verlag Gebrüder Bornträger, Berlin.

SPRENGER M. 1904. Über den anatomischen Bau der Bulbophyllinae. Dissertation, Heidelberg UniversitätsHeidelberg.

STACE C.A. 1965. Cuticular studies as an aid to plant taxonomy. Bulletin of the British Museum, Botany 4: $1-78$.

STACE C.A. 1984. The taxonomic importance of the leaf surface. In: HEYWOOD V.H. \& D.M. MOORE (eds.), current concepts in plant taxonomy. Academic Press, London. pp. 67-94.

STEBBINS G.L. \& G.S. KHUSH 1961. Variation in the organization of the stomatal complex in the leaf epidermis of monocotyledons and its bearing on their phylogeny. American Journal of Botany 48(1): 51-59.

STERN W.L. 1997a. Vegetative anatomy of subtribe Habenariinae (Orchidaceae). Botanical Journal of Linnean Society 125(3): 211-227. https://doi.org/10.1111/ j.1095-8339.1997.tb02255.x

STERN W.L. 1997b. Vegetative anatomy of subtribe Orchidinae (Orchidaceae). Botanical Journal of Linnean Society 124(2): 121-136. https://doi.org/10.1111/ j.1095-8339.1997.tb01786.x

STERN W.L. \& M.W. MORRIS 1992. Vegetative anatomy of Stanhopea (Orchidaceae) with special reference to pseudobulb water storage cell. Lindleyana 7(1): 34-53.

STERN W.L. \& B.S. CARLSWARD 2006. Comparative vegetative anatomy and systematics of Oncidiinae (Maxillarieae, Orchidaceae). Botanical Journal of the Linnean Society 152(1): 91-107. https://doi.org/ 10.1111/j.1095-8339.2006.00548.x
STERN W.L. \& B.S. CARLSWARD 2008. Vegetative anatomy of Calypsoeae (Orchidaceae). Lankesteriana 8(1): 105-112. http://dx.doi.org/10.15517/lank.v8i1. 3201

STERN W.L. \& B.S. CARLSWARD 2009. Comparative vegetative anatomy and systematics of Laeliinae (Orchidaceae). Botanical Journal of the Linnaean Society 160(1): 21-41. https://doi.org/10.1111/j.10958339.2009.00818.x

STERN W.L. \& W.S. JUDD 2000. Comparative vegetative anatomy and systematics of the orchid tribe Vanilleae excluding Vanilla (Orchidaceae). Botanical Journal of Linnean Society 134(1-2): 179-202. https://doi.org/ 10.1111/j.1095-8339.2000.tb02350.x

THEOBALD W.L., KRAUHLIK J.L. \& R.C. ROLLINS. Trichome description and classification. In: METCALFE C.R. \& L. CHALK (eds.), Anatomy of dicotyledons $2^{\text {nd }}$ edition, Vol.1. 1. Clarendon Press, New York, Oxford. pp. 45-53.

TOMINSKI P.W. 1905. Die Anatomie des Orchideenblattes in ihrer Abhängigkeit von Klima und Standort. Berlin.

TOMLINSON P.B. 1961. Anatomy of the Monocotyledons. Volume 2. Palmae. Clarendon Press, Oxford.

TOMLINSON P.B. 1969. Anatomy of the Monocotyledons. Volume 3. Commelinales-Zingiberales. Clarendon Press, Oxford.

VERMEULEN J.J. 1991. Orchids of Borneo: Bulbophyllum. Volume 2. Royal Botanic Gardens, Kew.

VIJ S.P., KAUSHAL P.S. \& P. KAUR 1991. Observations on leaf epidermal features in some Indian orchids: taxonomic and ecological implication. Journal of Orchid Society India 11: 93-97.

WANG Y.F. \& J.R. TAO 1993. Studies on the leaf cuticle of three Chinese endemic genera in Magnoliaceae. Acta Botanica Sinica 35: 106-110.

WILLIAMS N.H. 1974. The value of plant anatomy in orchid taxonomy. In: OSPINA M. (ed.), Proceedings of $7^{\text {th }}$ World Orchid Conference, Medellin, Colombia. pp. 281-298.

WILLIAMS N.H. 1975. Stomatal development in Ludisia discolour (Orchidaceae): mesoperigenous subsidiary cells in the monocotyledons. Taxon 24: 281-288. https:// doi.org/10.2307/1218336

WILLIAMS N.H. 1979. Subsidiary cells in the Orchidaceae: their general distribution with special reference to development in the Oncidieae. Botanical Journal of Linnean Society 78(1): 41- 66. https://doi.org/10.1111/ j.1095-8339.1979.tb02185.x

WILKINSON H.P. 1979. The plant surface. In: METCALF C.R. \& L. CHALK (eds.), Anatomy of the dicotyledons. Clarendon Press, Oxford. pp. 97-165. 
WITHNER C.L., NELSON P.K. \& P.J. WEJKSNORA 1974. The anatomy of orchids. In: WITHNER C.L. (ed.), The orchids: scientific studies. John Wiley, New York. pp. 267-347.

YANG S.J., SUN M., YANG Q.Y., MA R.Y., ZHANG J.L. \& S.B. ZHANG 2016. Two strategies by epiphytic orchids for maintaining water balance: thick cuticles in leaves and water storage in pseudobulbs. Annals of
Botany Plants 8: plw046. https://doi.org/10.1093/aobpla/ plw046

YUKAWA T., ANDO T., KARASAWA K. \& K. HASHIMOTO 1992. Existence of two stomatal shapes in the genus Dendrobium (Orchidaceae) and its systematic significance. American Journal of Botany 79(8): 946-952. https://doi.org/10.1002/j.1537-2197.1992. tb13678.x 